\title{
FORMATION OF SEEDLINGS OF SPECIES FROM THE GENUS PASSIFLORA UNDER SALINE STRESS
}

\author{
FORMAÇÃO DE MUDAS DE ESPÉCIES DO GÊNERO PASSIFLORA SOB \\ ESTRESSE SALINO
}

\author{
Regiana dos Santos MOURA ${ }^{1}$; Hans Raj GHEYI ${ }^{1}$; Mauricio Antônio COELHO FILHO ${ }^{2}$; \\ Onildo Nunes de JESUS ${ }^{2}$; Lucas Kennedy Silva LIMA ${ }^{1}$; Caliane Silva da CRUZ ${ }^{1}$ \\ 1. Federal University of Recôncavo of Bahia, Cruz das Almas Bahia, Brazil, E-mail: regianna.ufpi@gmail.com; 2. Empresa Brasileira \\ de Pesquisa Agropecuária - EMBRAPA, Cruz das Almas, Bahia, Brazil.
}

\begin{abstract}
The genus Passiflora of the passion fruit crop is the most important from economic point of view. However, its cultivation in the semi-arid region is at risk due to salinity problems, requiring the identification of tolerant species, which develop better in environments with salinity problems. The objective of this study was to evaluate the effects of water salinity on growth and formation of seedlings of three species from the genus Passiflora. The treatments were distributed in a completely randomized design, adopting a 5 x 3 factorial arrangement, with five levels of irrigation water salinity (ECw) of $0.3 ; 1.4 ; 2.5 ; 3.6$ and $4.7 \mathrm{dS} \mathrm{m}^{-1}$ and three species of Passiflora: gibertii; cincinnata and edulis 'BRS Gigante Amarelo', with four replicates. P. edulis surpassed the others in leaf area, shoot, root and total dry matter and Dickson index of seedling quality. Irrigation water salinity inhibits the formation of seedlings evaluated by growth in height, stem diameter and shoot, root and total dry matter of the studied species of Passiflora. The interaction between ECw and the Passiflora species interfered significantly in height, root, shoot and total dry matter and Dickson quality index. ECw above $0.3 \mathrm{dS} \mathrm{m}^{-1}$ affects the Dickson quality index of $P$. gibertii more,compared with $P$. edulis and $P$. cincinnata.
\end{abstract}

KEYWORDS: Salt stress. Passiflora spp.. Salinity tolerance.

\section{INTRODUCTION}

Passion fruit is a tropical plant native to South America from the Passifloraceae family, which has 17 genera and more than 600 species, of which 120 are from Brazil. The genus Passiflora is the most cultivated and thus the most important (PÉREZ, 2007).

Brazil is the main global producer of yellow passion fruit ( $P$. edulis Sims) and, in 2015, produced 695 thousand tons in 57 thousand hectares, with mean yield of $13.66 \mathrm{t} \mathrm{ha}^{-1}$. The Northeast region and the state of Bahia are responsible for 65 and $43 \%$ of the national production, respectively (IBGE, 2015). The wild species $P$. gibertii N. E. Br. and $P$. cincinnata Mast. are reported in the literature as important for the programs of genetic improvement, for being resistant to fusarium wilt and other diseases, besides having other attributes to be used as rootstocks (CAVICHIOLI et al., 2011; OLIVEIRA et al., 2013).

Although the Northeast region has expressive production of yellow passion fruit, it faces problems with the excess of salts in the soil and water, which compromise the formation and establishment of seedlings and consequently its production. This is due to the occasionally inadequate management of irrigation, associated with the problems of soil drainage and high evapotranspiration (CAVALCANTE et al., 2012). These authors report that any water, regardless of being from surface sources, underground sources or deep-water aquifers, contains salts in varied proportions that pose risk to irrigated agriculture.

Passion fruit can be propagated through seeds, cuttings and grafting. However, in Brazil, the predominant method is still the production of seedlings through sexual or seminiferous method, which is the simplest and most economical way for seedlings formation (WAGNER JUNIOR et al., 2007). Thus, water quality along with the substrate and physiological vigor of the seeds are determinant for a successful formation of seedlings. Yellow passion fruit seedlings are more sensitive to salinity during the initial growth stage than in the germination stage, and the damages caused by water salinity on the seedlings during their formation are due to direct and indirect, slow or abrupt, effects of the salts in the water on their development (NASCIMENTO et al., 2011).

The tolerance of crops to salinity, despite varying among species, genotypes, development stages, types of salts, nature and intensity of the stress (DIAS; BLANCO, 2010; SÁ et al., 2013; OLIVEIRA et al., 2015), can be evaluated through the capacity of the plant to tolerate levels of salts without losses in growth and production. Hence, various studies have evaluated the behavior of 
passion fruit cultivars in the search for viable alternatives to cope with salinity in semi-arid regions (LEITE et al., 2015). Casierra - Posada et al. (2013) consider P. edulis as "tolerant" to salinity in the germination stage and "moderately tolerant" to salinity in the other growth stages. In this context, the present study aimed to evaluate the effects of water salinity on the growth and formation of seedlings of three species from the genus Passiflora.

\section{MATERIAL AND METHODS}

The experiment was conducted from October to December 2015 in a protected environment of the Nucleus of Water and Soil Engineering (NEAS) of the Federal University of Recôncavo of Bahia (UFRB), Cruz das Almas - BA, Brazil, located at the geographic coordinates of $12^{\circ} 40^{\prime} 19^{\prime \prime} \mathrm{S}, 39^{\circ} 06^{\prime} 23^{\prime \prime} \mathrm{W}$ and mean altitude of 220 $\mathrm{m}$. The mean values of relative air humidity and temperature in the experimental period varied from 50.3 to $76.5 \%$ and from 19.3 to $34.6{ }^{\circ} \mathrm{C}$, (INMET, 2015), considered as adequate for passion fruit cultivation.

The treatments were distributed in a completely randomized design, in a $5 \times 3$ factorial scheme, corresponding to the levels of irrigation water salinity $(\mathrm{ECw})$ of 0.3 - control; $1.4 ; 2.5 ; 3.6$ and $4.7 \mathrm{dS} \mathrm{m}^{-1}$ and three species of Passiflora: gibertii; cincinnataand edulis ('BRS Gigante Amarelo'), with four replicates. The solutions of different salinity levels were prepared through the dissolution of $\mathrm{NaCl}$ in water from the local supply system, according to Eq. 1.

$\mathrm{mg} \mathrm{L}^{-1}(\mathrm{NaCl})=640 \mathrm{x}(\mathrm{EC} w$ desired $-\mathrm{EC} w$ actual) $\mathrm{Eq} .01$

The assay was conducted in containers made of PET bottles, with capacity for $2 \mathrm{dm}^{3}$, without the bottom part and placed upside down on a metal structure, with the hole facing down, connected through a drain to a recipient. The containers were filled up to $3 \mathrm{~cm}$ with gravel at the bottom part and then with a mixture of soil and decomposed bovine manure, at the proportion of 10:1 (mass basis), respectively.

The soil used to form the substrate was from the experimental area of the NEAS/UFRB (Yellow Latosol, with sandy loam texture, according to the Brazilian Soil Classification System - SiBCS (EMBRAPA, 2013). The substrate showed the following chemical attributes: $\mathrm{pH}=7.0 ; \mathrm{P}=139.00$ $\mathrm{mg} \mathrm{dm}{ }^{-3} ; \mathrm{K}^{+} ; \mathrm{Ca}^{2+} ; \mathrm{Mg}^{2+}$ and $\mathrm{Na}^{+}$with $3.08 ; 1.65$; 0.87 and $0.87 \mathrm{cmol}_{\mathrm{c}} \mathrm{dm}^{-3}$ respectively, and organic matter, sand, silt and clay with $7.00 ; 68.25 ; 20.22$;
$11.53 \mathrm{dag}^{-1}$, respectively, determined according to methodologies recommended by Embrapa (DONAGEMA et al., 2011).

Initially, the Passiflora species were sown on polyethylene trays containing the commercial substrate Vivatto ${ }^{\circledR}$ and irrigated with water from the municipal supply system $\left(E C w=0.30 \mathrm{dS} \mathrm{m}^{-1}\right)$. At 20 days after sowing (DAS), with the total emergence of the seedlings (with two true leaves), plants were transplanted to the containers. At 10 days after transplanting (DAT), plants began to be irrigated with different types of water. Irrigations were performed on alternate days and the applied water volume was calculated using Eq 02:

$\mathrm{VI}=\frac{(\mathrm{VA}-\mathrm{VD})}{0.9} \quad$ Eq. 02

Where: VI - water volume to be applied in irrigation; VA- water volume applied in the previous irrigation; VD - drained volume; and " 0.9 " is the factor to obtain a leaching fraction of 0.10 .

At 60 days after the beginning of the irrigations with saline water, the passion fruit plants were evaluated for growth and phytomass accumulation, based on plant height $(\mathrm{PH})$, number of leaves (NL), total leaf area (TLA), stem diameter (SD), root dry matter (RDM), shoot dry matter (SDM), total dry matter (TDM), RDM/SDM ratio, total water consumption (TWC) and Dickson quality index (DQI) of the seedlings. PH was measured as the distance from the base until the insertion of the apical meristem, while NL was obtained through manual count. TLA was estimated through the relationship between the dry matter of leaf discs of known area and TDW. SD was measured at $5.0 \mathrm{~cm}$ from the base of the plant. SDM and RDM were obtained after drying in an oven at temperature of $65{ }^{\circ} \mathrm{C}$ until constant weight, while water consumption was estimated through the difference between the applied and drained water volumes of each pot. DQI was determined using $\mathrm{Eq} 03$ (DICKSON et al., 1960).

$$
\mathrm{DQI}=\left[\frac{\mathrm{TDM}}{\left(\frac{F \mathrm{FD}}{\mathrm{SD}}\right)+\left(\frac{S D M}{\mathrm{RDM}}\right)}\right] \quad \text { Eq. } 03
$$

Where: DQI - Dickson quality index; TDM - total dry matter; PH - plant height; SD - stem diameter; SDM - shoot dry matter; RDM - root dry matter.

The results were subjected to analysis of variance by $\mathrm{F}$ test for the sources of variation. The variables with significant effect for the water salinity levels (quantitative factor) were analyzed using first- and second-degree polynomial regressions, whereas the passion fruit species 
(qualitative factor) were analyzed through comparison of means (Tukey test) at 0.05 probability level, using the statistical software SISVAR version 5.6 (FERREIRA, 2011).

\section{RESULTS AND DISCUSSION}

According to the summary of analysis of variance (Table 1 ), the interaction of water salinity $x$ species did not have significant effect on the evaluated variables, except plant height. Despite the lack of significance of the interaction, the growth in height, number of leaves, total leaf area and stem diameter responded to the isolated effects of the species $(\mathrm{p} \leq 0.01)$. In addition, water salinity significantly $(\mathrm{p} \leq 0.01)$ affected the height, stem diameter and total water consumption of the plants.

Table 1. Summary of the analysis of variance for plant height $(\mathrm{PH})$, number of leaves (NL), total leaf area (TLA), stem diameter (SD) and total water consumption (TWC) in passion fruit species under different levels of salinity, at 60 days after transplanting (DAT).

\begin{tabular}{llcccc}
\hline SV & \multicolumn{5}{c}{ Mean square } \\
\cline { 2 - 6 } & \multicolumn{1}{c}{ PH } & NL & TLA & SD & TWC \\
\hline Spécies (E) & $61386.00^{* *}$ & $700.8^{* *}$ & $396750.92^{* *}$ & $3.53^{* *}$ & $0.09^{\mathrm{ns}}$ \\
Salinity(S) & $2131.80^{* *}$ & $10.85^{\mathrm{ns}}$ & $6536.21^{\mathrm{ns}^{\mathrm{n}}}$ & $0.50^{* *}$ & $0.69^{* *}$ \\
E x S & $824.10^{* *}$ & $8.52^{\mathrm{ns}}$ & $9513.09^{\mathrm{ns}}$ & $0.06^{\mathrm{ns}}$ & $0.10^{\mathrm{ns}}$ \\
\hline Means (Spécies) & $\mathrm{cm}$ & & $\mathrm{cm}^{2}$ & $\mathrm{~mm}$ & $\mathrm{~L}$ plant $^{-1}$ \\
$P$. gibertii & $168.75 \mathrm{a}$ & $22.50 \mathrm{a}$ & $284.81 \mathrm{~b}$ & $3.86 \mathrm{~b}$ & $2.59 \mathrm{a}$ \\
$P$. cincinnata & $161.55 \mathrm{a}$ & $14.85 \mathrm{~b}$ & $171.06 \mathrm{c}$ & $3.60 \mathrm{~b}$ & $2.48 \mathrm{a}$ \\
$P$. edulis & $69.39 \mathrm{~b}$ & $10.85 \mathrm{c}$ & $451.11 \mathrm{a}$ & $4.41 \mathrm{a}$ & $2.60 \mathrm{a}$ \\
\hline M. global & 133.23 & 16.06 & 302.33 & 3.96 & 2.56 \\
CV $(\%)$ & 12.31 & 16.83 & 24.56 & 8.22 & 9.77 \\
\hline
\end{tabular}

ns, $* *$ and $*=$ not significant, significant at 0.01 and 0.05 probability level, respectively.

Based on the results of Figure 1, P. edulis grew less in height compared with the other species. The increase in the saline concentration of the water up to the maximum estimated $\mathrm{ECw}$ of $2.17 \mathrm{dS} \mathrm{m}^{-1}$ stimulated the growth in height of the seedlings, reaching the maximum value of $91.32 \mathrm{~cm}$. Irrigation with $\mathrm{ECW}$ above this limit inhibited the growth in height of the seedlings of this species. Regarding $P$. cincinnata and $P$. gibertii, despite the high values, the data did not fit to any mathematical model and the results were represented by the mean values of 161.54 and $168.62 \mathrm{~cm}$, respectively, regardless of the irrigation water salinity. The differences in height between the species may be related to genetic characteristics (BERNSTEIN, 1974). Lima et al. (2006) studying the germination test at 14 days after emergence observed similar trend, the specie $P$. gibertii showed the greatest height of $40.4 \mathrm{~cm}$, being superior to $P$. edulis, $P$. laurifolia and $P$. alata, which showed means of 22.2, 17.5 and 18.8 $\mathrm{cm}$, respectively.

Mesquita et al. (2012) evaluated the height of $P$. edulis subjected to salinity in soil with and without bovine biofertilizer, at 65 days after transplanting, treatment without biofertilizer led to highest height of $58.3 \mathrm{~cm}$ at ECw of $0.5 \mathrm{dS} \mathrm{m}$, which is lower than that obtained in the present study $(61.07 \mathrm{~cm})$ at $\mathrm{ECW}$ of $0.3 \mathrm{dS} \mathrm{m} \mathrm{m}^{-1}$. This behavior is possibly due to the high concentrations of sodium in the solutions of higher electrical conductivity, which negatively interacts with plant physiology, promoting deleterious ionic, osmotic and nutritional effects on plants, compromising their growth and biomass accumulation (MUNNS \& TESTER, 2008; SÁ et al., 2013). Souza et al. (2016) observed that the ECw of $4.00 \mathrm{dS} \mathrm{m}^{-1}$ did not affect the growth of P.edulis in sandy soil.

For the follow-up analysis of the factor salinity in the species (Figure 1B), there was positive effect of $\mathrm{ECw}$ on $\mathrm{PH}$ with greater growth for the species $P$. gibertii and $P$. cincinnata at the level of $1.4 \mathrm{dS} \mathrm{m} \mathrm{m}^{-1}$. The species $P$. edulis was significantly affected only at the highest level of salinity $\left(4.7 \mathrm{dS} \mathrm{m}^{-1}\right)$. This response of the species $P$. gibertii and $P$. cincinnata may be related to the genetic characteristics of these species. According to Farias et al. (2009), some species can accumulate ions in the vacuole and organic solutes of low molecular weight in the cytoplasm, which allows an osmotic adjustment to this type of condition. 

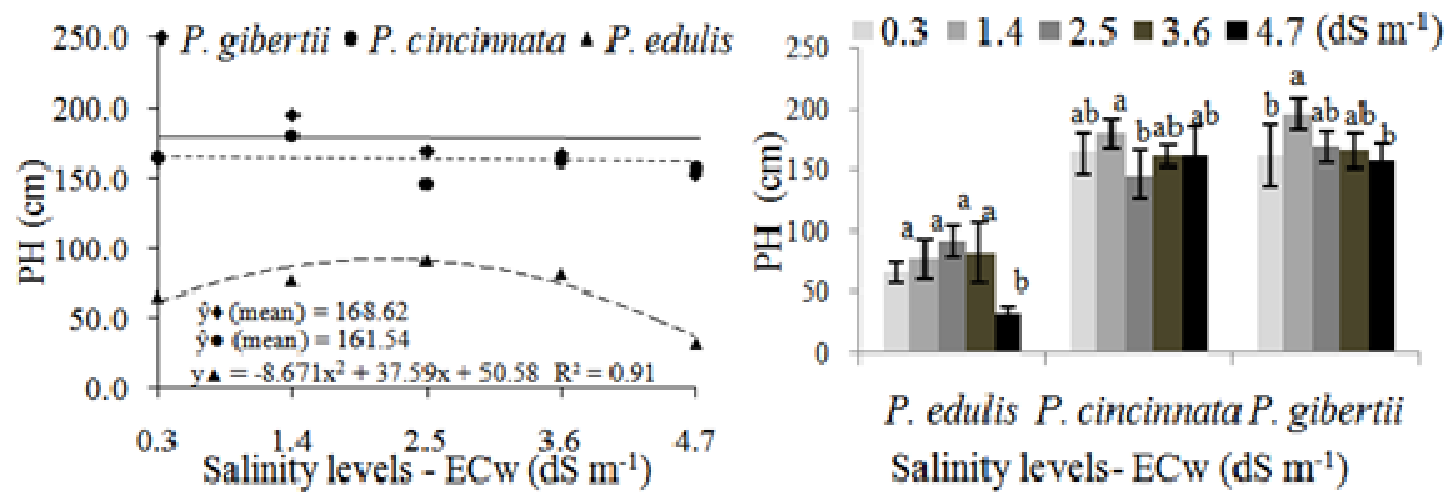

Figure 1. (A) Follow-up analysis of the factor species inside the factor irrigation water salinity (ECw) and (B) factor salinity $(\mathrm{ECw})$ inside the factor passion fruit species for plant height, at 60 days after transplanting under different levels of irrigation water salinity.

In relation to the means of NL observed for the different species, the highest $(\mathrm{p}<0.01)$ number of leaves occurred for P. gibertii, 51.51 and $107.37 \%$ higher in relation to the species $P$. cincinnata and $P$. edulis, respectively (Figure 2A). However, the highest number of leaves exhibited by the $P$. gibertii did not result in greater leaf area per plant. In general, among the previously mentioned species, $P$. cincinnata has the lowest means of leaf area, being a morphological characteristic of the species (smallsized, narrower leaves). P. edulis, although showing the lowest NL, has higher TLA, with superiority of 163.71 and $58.38 \%$ in relation to $P$. cincinnata and $P$. gibertii, respectively (Figure 2B).
This result differs from that obtained by Sousa et al. (2013) in the Passiflora species $P$. edulis, $P$. alata and $P$. ligularis. These authors observed significant difference for NL between the species at 70 days after transplanting. It should be highlighted the order of the values obtained in the variables $\mathrm{PH}$ and $\mathrm{NL}$, which was $P$. gibertti $>P$. cincinnata $>P$. edulis, for LA, it was $P$. edulis $>P$. gibertti $>P$. cincinnata, because $P$. edulis has greater area per leaf there fore, even with fewer leaves per plant, the total leaf area was higher than those of $P$. gibertti and P. cincinnata.
A

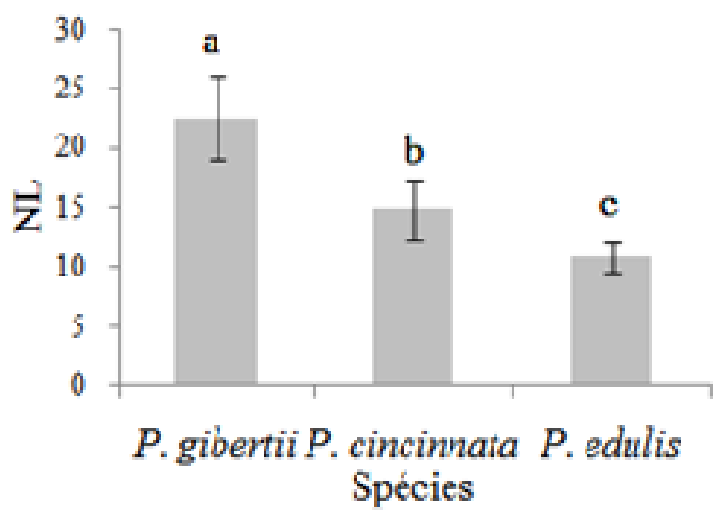

B

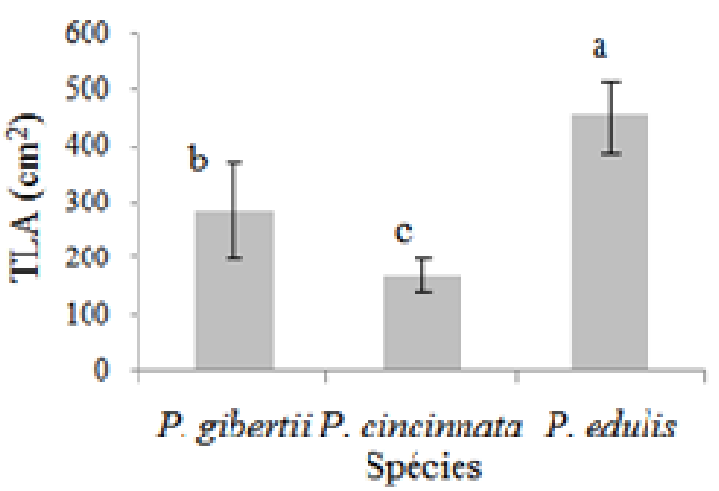

Figure 2. (A) Mean number of leaves (NL) and (B) total leaf area (TLA) of the passion fruit species at 60 days after transplanting under different levels of irrigation water salinity.

For the studied species, $P$. edulis showed the highest SD $(4.41 \mathrm{~mm})$, being 14.24 and $22.50 \%$ superior $(\mathrm{p}<0.01)$ to $P$. gibertii and $P$. cincinnata, respectively (Table 1 ). Such superiority, as observed for TLA, can be a response of the specific morphological characteristics of each species to the action of salinity. Based on the results of Figure 3A, there was a reduction of $2.64 \%$ in stem diameter per unit increase in water salinity, which corresponds to a decrease of $11.66 \%$ between plants irrigated with water of highest and lowest saline levels. This behavior is due to the reduction in the absorption of 
water and nutrients by the roots resulting from the decrease in the osmotic potential of the soil solution, which retards the development and accumulation of photoassimilates in the stem of the passion fruit seedlings. The observed results corroborate those of Oliveira et al. (2015), who found reductions of $11.08 \%$ in the SD of $P$. edulis due to the increment in $\mathrm{ECw}$ from 0.3 to $3.5 \mathrm{dS} \mathrm{m}^{-1}$.

Figure $3 \mathrm{~B}$ shows the linear reduction of $4.48 \%$ in the total water consumption per unit
MOURA, R. S. et al

increase in the electrical conductivity of the irrigation water (ECw). Decrease in water consumption under salt stress conditions was also observed in other crops, such as castor bean, by Nobre et al. (2014), of the order of $11.31 \%$ per unit increase in ECW. The reduction in TWC contributed to decrease the capacity of production of organic photoassimilates and resulted in lower growth (height and diameter) of the plants, as also found in $P$. edulis by Ariel Montana et al. (2014).
A

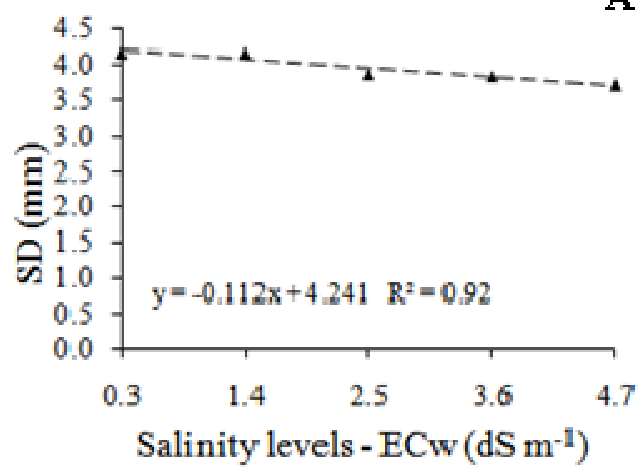

B

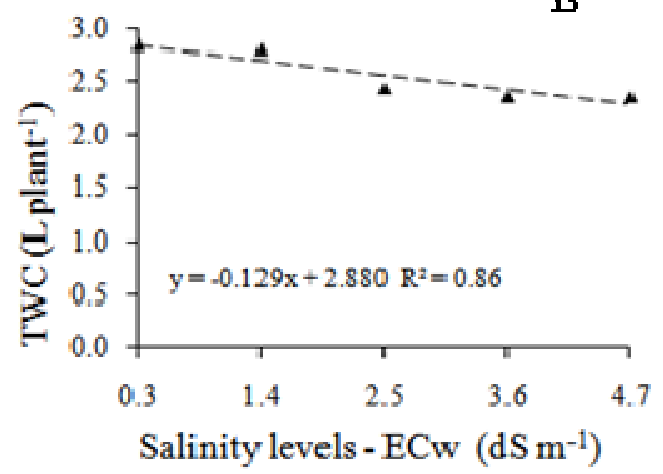

Figure 3. Stem diameter - SD (A) and total water consumption - TWC (B) for passion fruit seedlings at 60 days after transplanting under different levels of irrigation water salinity $(\mathrm{ECW})$.

The formation of dry matter by the different plant organs and the quality of the seedlings (SDM, RDM, RDM/SDM, TDM and DQI) were influenced $(\mathrm{p} \leq 0.01)$ by both the isolated factors and the interaction between water salinity and passion fruit species at 60 days after transplanting, except $\mathrm{RDM} / \mathrm{SDM}$ in the factor salinity, which was significant at $\mathrm{p} \leq 0.05$ (Table 2).

Table 2. Summary of the analysis of variance for shoot dry matter (SDM), root dry matter (RDM), root dry matter/shoot dry matter ratio (RDM/SDM), total dry matter (TDM) and Dickson quality index (DQI) in passion fruit species under different levels of salinity, at 60 days after transplanting (DAT).

\begin{tabular}{llllll}
\hline \multirow{2}{*}{ SV } & \multicolumn{5}{c}{ Mean square } \\
\cline { 2 - 6 } & SDM & RDM & RDM/SDM & TDM & DQI \\
\hline Spécies (E) & $25.46^{* *}$ & $19.88^{* *}$ & $0.39^{* *}$ & $74.44^{* *}$ & $1.36^{* *}$ \\
Salinity(S) & $3.61^{* * *}$ & $1.30^{* *}$ & $0.02^{* *}$ & $8.87^{* * *}$ & $0.03^{* *}$ \\
E X S & $1.36^{* *}$ & $1.24^{* *}$ & $0.09^{* *}$ & $2.19^{* *}$ & $0.04^{* *}$ \\
Means (Spécies) & & & & & \\
P. gibertii & $5.47 \mathrm{a}$ & $2.41 \mathrm{~b}$ & $0.44 \mathrm{c}$ & $7.88 \mathrm{~b}$ & $0.17 \mathrm{~b}$ \\
$P$. cincinnata & $3.43 \mathrm{~b}$ & $1.90 \mathrm{c}$ & $0.55 \mathrm{~b}$ & $5.33 \mathrm{c}$ & $0.11 \mathrm{c}$ \\
$P$. edulis & $5.29 \mathrm{a}$ & $3.83 \mathrm{a}$ & $0.72 \mathrm{a}$ & $9.12 \mathrm{a}$ & $0.59 \mathrm{a}$ \\
\hline M. global & 4.73 & 2.71 & 0.57 & 7.44 & 0.29 \\
CV $(\%)$ & 6.53 & 10.67 & 13.70 & 5.43 & 22.32 \\
\hline
\end{tabular}

ns,** and $*=$ Not significant, significant at 0.01 and 0.05 probability level, respectively.

For SDM, in the follow-up analysis of the factor species inside the factor salinity, there was a linear reduction of $7.54 \%$ per unit increase in $\mathrm{ECw}$ in $P$. cincinnata, while the species $P$. edulis and $P$. gibertii showed quadratic responses with highest $\mathrm{SDM}$ values of 5.76 and $6.10 \mathrm{~g}$ obtained at the $\mathrm{ECW}$ levels of 2.03 and $1.15 \mathrm{dS} \mathrm{m}^{-1}$, respectively (Figure 4A). It should be highlighted that Bezerra et al.
(2014) observed reduction in SDM for P. edulis of $3 \%$ as the electrical conductivity of the irrigation water increased from 0.3 to $4.0 \mathrm{dS} \mathrm{m}^{-1}$.

In the follow-up analysis of the factor salinity inside the factor species, with respect to SDM, there was significant difference for $P$. edulis only at the ECw of $4.7 \mathrm{dS} \mathrm{m}{ }^{-1}$ with lowest value, while $P$. cincinnata obtained highest value at $\mathrm{ECw}$ 
of $0.3 \mathrm{dS} \mathrm{m} \mathrm{m}^{-1}$ (control), differing from the other treatments, and $P$. gibertii showed significant differences at the two highest $\mathrm{ECw}$ levels (3.6 and $4.7 \mathrm{dS} \mathrm{m}^{-1}$ ) in relation to the other treatments (Figure 4B). This reduction in SDM at the highest
$\mathrm{ECw}$ levels is attributed to the decrease in photosynthesis and delay in the development of apical buds caused by the salt stress (NASCIMENTO et al., 2011).

A

$\mathbf{B}$
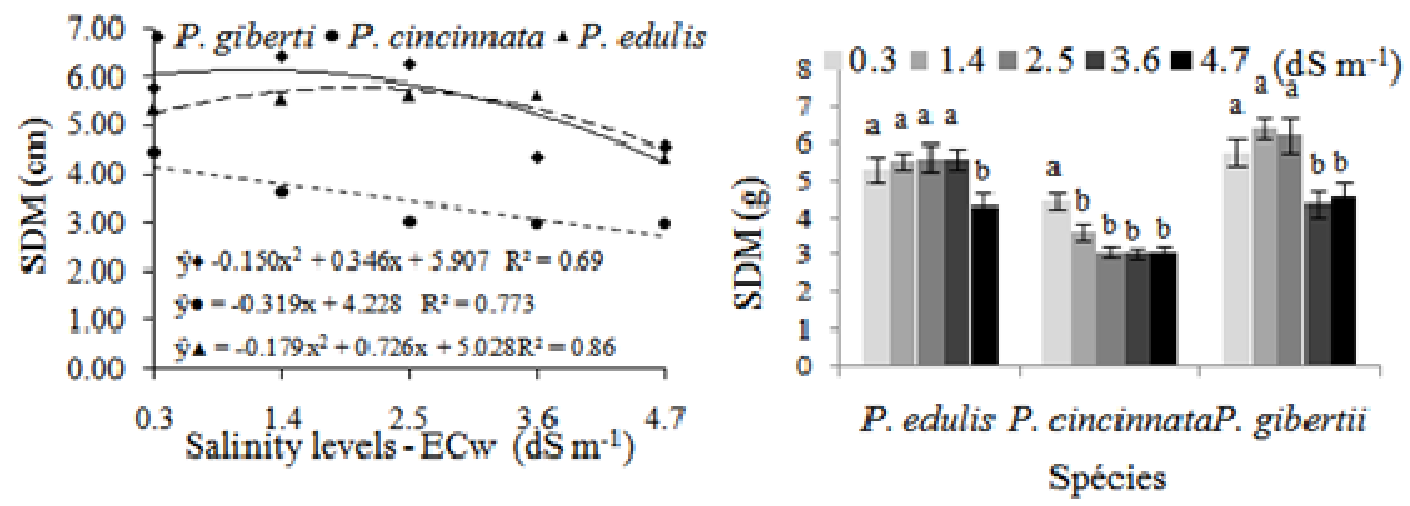

Figure 4. Follow-up analysis of the factor passion fruit species inside the factor salinity - ECw (A) and factor salinity (ECw) inside the factor passion fruit species (B) for shoot dry matter, at 60 days after transplanting.

The RDM of $P$. edulis was linearly affected with decrease of $5.73 \%$ per unit increase in $\mathrm{ECw}$. The species $P$. gibertii and $P$. cincinnata maximized $\mathrm{RDM}$ in 2.41 and $2.84 \mathrm{~g}$ at the ECw levels of 0.66 and $2.97 \mathrm{dS} \mathrm{m} \mathrm{m}^{-1}$, respectively (Figure $5 \mathrm{~A}$ ). This reduction in passion fruit root growth with the increase in ECw can be attributed to the decrease in water absorption evidenced by the TWC and, therefore, it tends to affect the growth and development of the different plant parts, SDM (Figure 4B) and RDM (Figure 5A).

Similar results were observed by Oliveira $e t$ al. (2015) in P. edulis seedlings due to the increase in irrigation water salinity. These authors reported reductions of $65.8 \%$ in $\mathrm{RDM}$ as $\mathrm{ECW}$ increased from 0.3 to $3.5 \mathrm{dS} \mathrm{m}^{-1}$. However, in the present study, this reduction for $P$. edulis under the same conditions was lower (48.87\%), possibly because of the different types of substrates and environmental conditions.
The interaction between species and salinity levels for the variable RDM/SDM ratio showed different responses for the three species. P. gibertii did not respond to salinity, being represented by the mean (0.73); P. edulis exhibited an increasing linear response, with $20.87 \%$ per unit increase in irrigation water salinity; and $P$. cincinnata showed highest $\mathrm{RDM} / \mathrm{SDM}$ ratio (0.69) at the ECW of $2.01 \mathrm{dS} \mathrm{m}^{-1}$ (Figure 5B). It is worthwhile to mention that all species showed RDM/SDM ratio lower than 1.0 irrespective of treatments, indicating that SDM was higher than RDM.

It is suggested that $P$. edulis uses physiological mechanisms in situations of salt stress to retard root system development and directs photoassimilates to the shoots, to use them under more-favorable conditions. Salinity-tolerant plants can accumulate high amounts of salts extracted from the soil in their tissues (SANTOS et al., 2011). 
A B
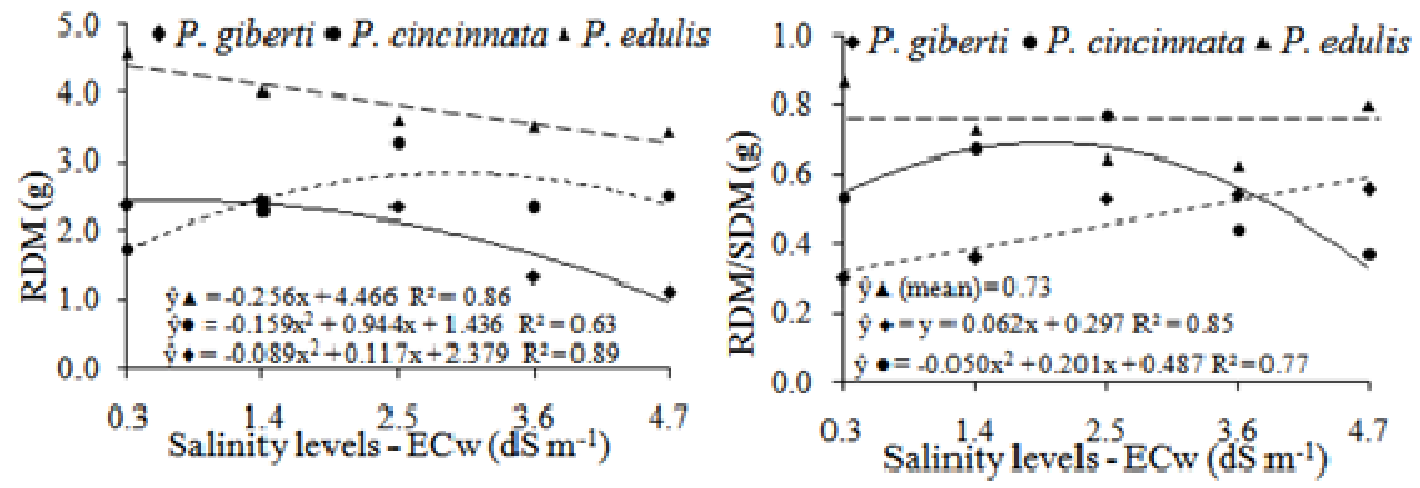

Figure 5. Interaction of species $x$ salinity levels for root dry matter - RDM (A) and root dry matter/shoot dry matter ratio - RDM/SDM (B) in passion fruit at 60 days after transplanting.

In the interaction of species $\mathrm{x}$ water salinity, $P$. edulis and $P$. cincinnata suffered reductions of 4.19 and $9.28 \%$ in TDM per unit increase in ECw, respectively (Figure 6A). As to the TDM for $P$. gibertii, the results were not affected by the salinity, showing a mean value of $7.88 \mathrm{~g}$. Correia et al. (2009) claim that the allocation of biomass in certain plant organs is a different strategy as the stress levels are intensified. This behavior was similar to those observed in other species, such as $P$. Tripartite var. mollissima by Casierra-Posada et al. (2013), who reported drastic reductions in the accumulation of total dry matter due to the increment in salinity.

According to the results of the Dickson quality index (DQI), $P$. gibertii seedlings evaluated at 60 days under saline water irrigation (Figure 6B) exhibited a sharp decrease $(9.74 \%)$ per unit increase in ECw. Still based on Figure 6B, $P$. edulis and $P$. cincinnata seedlings were not affected by the salinity levels, being represented by the means 0.59 and 0.12 , respectively. An interesting fact is that $P$. edulis seedlings, even under saline stress conditions, showed DQI above 0.2 , being considered of good quality for the establishment in the field, according to the criteria established by Gomes et al. (2003), because the higher the DQI value, the better the quality of the seedling.

Considering that the Dickson quality index is based on the relationship of total dry matter in relation to height and diameter and on the biomass allocation of roots and shoots, the low DQI for the wild species $P$. cincinnata and $P$. gibertii can be justified by the variables in the denominator of the DQI equation (Eq. 2), especially the $\mathrm{PH}$ of these species, which grew more than $160 \mathrm{~cm}$ in height (Figure 1A), leading to a very low value of DQI (Figure 6B).

A

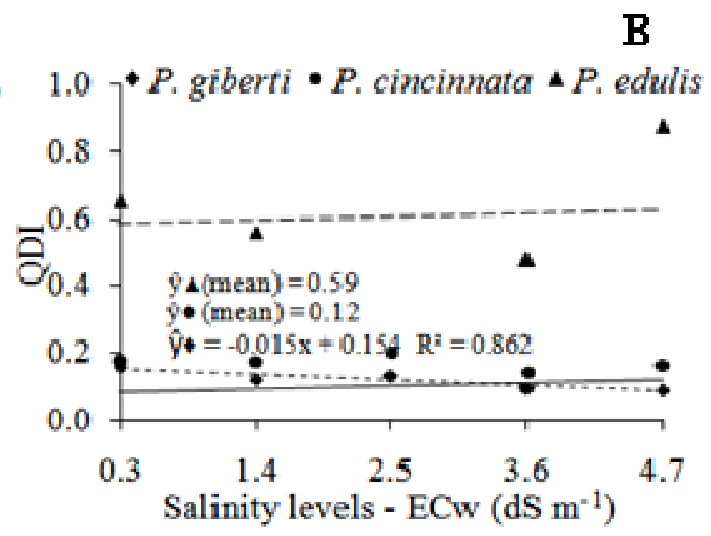

Figure 6. Interaction of species $x$ salinity levels for total dry matter - TDM (A) and Dickson quality index DQI (B) for the production of passion fruit seedlings, at 60 days after transplanting.

There is no information in the literature on the DQI for passion fruit under saline stress. However, in studies with percentage of bovine manure in the composition of the substrate, Dantas et al. (2012) observed highest estimated value of 0.2 for DQI in P. edulis, recommended dose of $41.4 \%$ 
of bovine manure in the substrate composition. Almeida et al. (2011), studying the production of yellow passion fruit seedlings on trays, using the substrates " $50 \%$ soil $+50 \%$ bovine manure" and " $50 \%$ soil $+50 \%$ goat manure" obtained the highest values of DQI, 1.2 and 1.5, respectively. In the present study, $P$. edulis seedlings showed DQI of 0.59 , being considered of good quality.

\section{CONCLUSIONS}

Irrigation water salinity inhibits the growth in height, stem diameter and shoot, root and total dry matter of the Passiflora species.
The interaction between the irrigation water salinity and the Passiflora species significantly interferes with height, root, shoot and total dry matter, total water consumption and Dickson quality index of seedlings.

Among the species, $P$. edulis surpassed the others in total leaf area, shoot, root and total dry matter, root dry matter/shoot dry matter ratio and Dickson quality index.

Irrigation with water of electrical conductivity of $0.3 \mathrm{dS} \mathrm{m} \mathrm{m}^{-1}$ compromises the Dickson quality index of seedling of the species $P$. gibertii and $P$. cincinnata.

RESUMO: O gênero Passiflora da cultura do maracujazeiro é o importante de ponto de vista econômico. No entanto, seu cultivo na região semiárida apresenta risco, devido aos problemas de salinidade, sendo necessária a identificação de espécies tolerantes, que se desenvolvam em ambientes com problemas de salinidade. Com isso, objetivouse avaliar os efeitos da salinidade das águas no crescimento e formação de mudas de três espécies do gênero Passiflora. Os tratamentos foram distribuídos em delineamento inteiramente casualizado, usando arranjo fatorial $5 \times 3$, com cinco níveis de salinidade da água de irrigação (CEa) de 0,3; 1,4; 2,5; 3,6 e 4,7 dS m e três espécies de Passiflora: gibertii; cincinnata e edulis BRS Gigante Amarelo, com quatro repetições. Dentre as espécies, $P$. edulis superou as demais em área foliar, matéria seca da parte aérea, de raiz e total e índice de qualidade de mudas de Dickson. A salinidade da água de irrigação inibe a formação de mudas avaliadas pelo crescimento em altura, diâmetro do caule, massa seca das partes aérea, raiz e total, das espécies estudadas. A interação entre $\mathrm{CEa}$ e as espécies de Passiflora interfere significativamente na altura, massa seca das aízes, parte aérea, total e índice de qualidade de Dickson das mudas. A irrigação com CEa acima de 0,3 dS $\mathrm{m}^{-1}$ compromete mais o índice de qualidade de Dickson da espécie $P$. gibertii que das espécies $P$. edulis e $P$. cincinnata.

PALAVRAS-CHAVE: Estresse salino. Passiflora spp. Tolerância à salinidade.

\section{REFERENCES}

ALMEIDA, J. P. N.; BARROS, G. L.; SILVA, G. B. P.; PROCÓPIO, I. J. S.; MENDONÇA, V. Substratos alternativos na produção de mudas de maracujazeiro amarelo em bandeja. Revista Verde de Agroecologia e Desenvolvimento Sustentável, Mossoró, v. 6, n. 1, p. 188-195, 2011. Link:

http://www.gvaa.com.br/revista/index.php/RVADS/article/view/626/545

ARIEL MONTAÑA, L; FISCHER, G.; MAGNITSKIY, S; ZULUAGA, G. Effect of NaCl salinity on seed germination and seedling emergence of purple passion fruit (Passiflora edulis Sims) Agronomía Colombiana, Bogota, v. 32, n. 2, p. 188-195, 2014. DOI: https://doi.org/10.15446/agron.colomb.v32n2.38287

BERNSTEIN, L. Crop growth and salinity. In: SCHILFGAARD, J. van (ed.). Drainage for agriculture. Madison: American Society of Agronomy, 1974. cap. 3, p. 39-54. (Agronomy, 17)

BEZERRA, M. A. F.; PEREIRA, W. E.; BEZERRA, F. T. C.; CAVALCANTE, L. F.; MEDEIROS, S. A. S. Água salina e nitrogênio na emergência e biomassa de mudas de maracujazeiro amarelo, Agropecuária Técnica, Areia, v. 35, n. 1, p. 150-160, 2014.

Link:http://periodicos.ufpb.br/index.php/at/article/viewFile/19920/12361

CASIERRA-POSADA, F.; PEÑA-OLMOS, J. E.; VAUGHAN, G. Photochemical efficiency of photosystem II and growth in banana Passion fruit plants (Passiflora tripartite (Juss.) var. mollissima(Kunt) L.H. Bailey under salt stress, Acta Agronómica, Sede Palmira, v. 62, n.1, p. 21-26,2013.Link:

https://www.researchgate.net/publication/259464360_Photochemical_efficiency_of_photosystem_II_and_grow 
th_in_banana_passionfruit_plants_Passiflora_tripartita_Juss_var_mollissima_Kunt_LH_Bailey_under_salt_stre SS

CAVALCANTE, L. F. A água para agricultura: Irrigação com água de boa qualidade e água salina. In: CAVALCANTE, L. F.; OLIVEIRA, F. A.; GHEYI, H. R.; CAVALCANTE, I. H. L.; SANTOS, P. D. O maracujazeiro amarelo e a salinidade, João Pessoa, 2012.p. 17-67.

CAVICHIOLI, J. C.; CORRÊA, L. de S.; BOLIANI, A. C.; SANTOS, P. C. Desenvolvimento e produtividade do maracujazeiro-amarelo enxertado em três porta-enxertos. Revista Brasileira de Fruticultura, Jabuticabal, v. 33, p. 558-566, 2011. Link: http://www.scielo.br/pdf/rbf/v33n2/AOP04311.pdf

CORREIA, K. G.; FERNANDES, P. F.; GHEYI, H. R.; NOBRE, R. G.; SANTOS, T. da S. Crescimento, produção e características de fluorescência da clorofila $a$ em amendoim sob condições de salinidade. Revista Ciência Agronômica, Fortaleza, v. 40, n. 4, p. 514-521, 2009. Link:

http://www.ccarevista.ufc.br/seer/index. php/ccarevista/article/view/542

DANTAS, L. L. G. R.; LEITE, G. A.; TOSTA, M. S.; GÓES, G. B.; FREIRE TOSTA, P. A.; MARACAJÁ, P. B. Esterco bovino no desenvolvimento inicial de maracujazeiro-amarelo. Revista Verde de Agroecologia e Desenvolvimento Sustentável, Mossoró, v. 7, n. 4, p. 101-107, 2012. Link:

http://www.gvaa.com.br/revista/ index.php/RVADS/article/view/1800

DIAS, N. da S.; BLANCO, F. F. Efeitos dos sais no solo e na planta. In: GHEYI, H. R.; DIAS, N. da S.; LACERDA, C. F. de. (ed.) Manejo da salinidade na agricultura: Estudos básicos e aplicados. Fortaleza: INCTSal, 2010, cap. 9, p. 129-142.

DICKSON, A.; LEAF A. L.; HOSNER, J. F. Quality appraisal of white spruce and white pine seedling stock in nurseries. Forestry Chronicle, Mattawa, v. 36, n. 1. p. 10-13, 1960. Link: http://pubs.cif-ifc.org/doi/abs/ 10.5558/tfc36010-1

DONAGEMA, G. K.; CAMPOS, D. V. B.; CALDERANO, S. B.; TEIXEIRA, W. G.; VIANA J. H. M. Manual de métodos de análises de solos. 2. ed. Rio de Janeiro: Embrapa Solos, 2011. 230 p. (Documentos / Embrapa Solos; 132).

EMBRAPA. Centro Nacional de Pesquisa de Solos. Sistema brasileiro de classificação de solos, 3. ed. revista e ampliada, Brasília: Embrapa Solos, 2013, 342 p.

FARIAS, S. G. G.; SANTOS, D. R.; FREIRE, A. L. O.; SILVA, R. B. Estresse salino no crescimento inicial e nutrição mineral de gliricídia (Gliricidiasepium (Jacq.) Kunth ex Steud) em solução nutritiva. Revista

Brasileira de Ciência do Solo,Viçosa, v. 33, n. 5, p. 1499-1515, 2009. DOI.org/10.1590/S010006832009000500040

FERREIRA, D. F. Sisvar: Acomputer statistical analysis system. Ciência e Agrotecnologia, Lavras, v. 35, n. 6, p. 1039-1042, 2011. DOI.org/10.1590/S1413-70542011000600001

GOMES, J. E. M.; COUTO, L.; LEITE, H. G.; XAVIER, A.; GARCIA, S. L. R. Crescimento de mudas de Eucalyptus grandis em diferentes tamanhos de tubetes e fertilização N-P-K. Revista Árvore, Viçosa, v. 27, n. 2, p. 113-127, 2003. Link: http://www.scielo.br/pdf/rarv/v27n2/15930.pdf

IBGE - Instituto Brasileiro de Geografia e Estatística. Produção agrícola em 2015. Disponível em: $<\mathrm{http}: / / \mathrm{www} \cdot$ sidra.ibge.gov.br/bda/agric/default.asp?t=4\&z=t\&o=11\&u1=1\&u2=27\&u3=1\&u 4=27\&u5=1\&u6=1>. Acesso em: 03 de julho de 2016.

INMET - Instituto Nacional de Meteorologia/BDMEP - Banco de Dados Meteorológicos para ensino e pesquisa. 2015. Disponível em: <http://www.inmet.gov.br/projetos/rede/pesquisa/ mapas_mensal_sem.php>. Acesso em 03 de julho de 2016. 
LEITE, M. J. H.; GOMES, A. D. V.; SANTOS, R. V. Comportamento inicial do maracujazeiro em solos afetados por sais submetidos a tratamentos alternativos com o uso de co-produtos de mineradoras. Irriga, Botucatu, v. 20, n. 3, p. 401-413, 2015. Link: http://irriga.fca.unesp.br/index.php/irriga/article/view/574

LIMA, A. A.; CALDAS, R. C.; SANTOS, V. S. Germinação e crescimento de espécies de maracujá. Revista Brasileira de Fruticultura, Jabuticabal, v. 28, n. 1, p. 125-127, 2006. DOI.org/10.1590/S010029452006000100034

MESQUITA, F. O.; CAVALCANTE, L. F.; PEREIRA, W. E.; REBEQUI, A. M.; LIMA NETO, A. J. NUNES, J. C. Produção de mudas de maracujazeiro amarelo submetidas à salinidade em solo com biofertilizante bovino. Asociacion Argentina Ciencia Del Suelo, Oliveros v. 30, n. 1, p. 31-41, 2012. Link: http://www.scielo.org.ar/ scielo.php?script=sci_arttext\&pid=S1850-20672012000100004

MUNNS, R.; TESTER, M. Mechanisms of salinity tolerance. Annual Review of Plant Biology, Palo Alto v. 59, n. 6, p. 651-681, 2008. DOI: 10.1146/annurev.arplant.59.032607.092911.

NASCIMENTO, J. A. M.; CAVALCANTE, L. F.; SANTOS, P. D.; SILVA, S. A.; VIEIRA, M. S.; OLIVEIRA, A. P. Efeito da utilização de biofertilizante bovino na produção de mudas de pimentão irrigadas com água salina. Revista Brasileira de Ciências Agrárias, Recife, v. 6, n. 2, p. 258-264, 2011.Link: http://www.agraria.pro.br/sistema/index.php?journal=agraria\&page=article\&op=viewArticle\&path $\% 5 \mathrm{~B} \% 5 \mathrm{D}=\mathrm{a}$ graria_v6i2a1069

NOBRE, R. G.; LIMA, G. S.; GHEYI, H. R.; ANJOS SOARES, L. A.; SILVA, A. O. Crescimento, consumo e eficiência do uso da água pela mamoneira sob estresse salino e nitrogênio. Revista Caatinga, Mossoró, v. 27, n. 2, p. 148-158, 2014. Link: https://periodicos.ufersa.edu.br/revistas/index.php/sistema/article /viewFile/ 2739/pdf_123

OLIVEIRA, F. A.; LOPES, M. A. C.; SÁ, F. V. S.; NOBRE, R. G.; MOREIRA, R. C. L., SILVA, L. A.; PAIVA, E. P. Interação salinidade da água de irrigação e substratos na produção de mudas de maracujazeiro amarelo. Comunicata Scientiae, Bom Jesus, v. 6, n. 4, p. 471-478, 2015. DOI: 10.14295/CS.v6i4.982 https://doi.org/10.14295/cs.v6i4.982

OLIVEIRA, E. J.; SOARES, T. L.; BARBOSA, C. J., SANTOS-FILHO, H. P.; JESUS, O. N. Severidade de doenças em maracujazeiro para identificação de fontes de resistência em condições de campo. Revista Brasileira de Fruticultura, Jabuticabal, v. 35, n. 2, p. 485-492, 2013. DOI.org/10.1590/S010029452013000200018

PÉREZ, J. O.; D’EECKENBRUGGE, G. C.; RESTREPO, M.; JARVIS, A.; MIKE SALAZAR, M.; CAETANO, C. Diversity of Colombian Passifloraceae: Biogeography and an up dated list for conservation. Biota Colombiana, Bogotá v. 8, n. 1, p. 1 - 45, 2007. Link: http://www.redalyc.org/articulo.oa?id=49180101

SANTOS, K. C. F.; SILVA, M. S. L.; SILVA, L. E.; MIRANDA, M. A.; FREIRE, M. B. G. S. Atividade biológica em solo salino sódico saturado por água sob cultivo de Atriplex nummularia. Revista Ciência Agronômica, Fortaleza, v. 42, n. 3, p. 619-627, 2011. Link:

http://www.ccarevista.ufc.br/seer/index.php/ ccarevista/article/view/1747

SÁ, F. V. S.; BRITO, M. E. B.; MELO, A. S.; ANTÔNIO NETO, P.; FERNANDES, P. D.; FERREIRA, I. B. Produção de mudas de mamoeiro irrigadas com água salina. Revista Brasileira Engenharia Agrícola e Ambiental, Campina Grande, v. 17, n. 10, p. 1047-1054. 2013. Link:

http://www.scielo.br/pdf/rbeaa/ v17n10/04.pdf

SOUSA, L. B.; HEITOR, L. C.; SANTOS, P. C.; FREITAS, J. A. A.; FREITAS, M. S. M.; FREITAS, S. J.; CARVALHO, A. J. C. Crescimento, composição mineral e fenóis totais de espécies de Passiflora em função de fontes nitrogenadas. Bragantia, Campinas, v. 72, n. 3, p. 247-254, 2013. DOI.org/10.1590/brag.2013.034 https://doi.org/10.1590/brag.2013.034 
SOUZA, J. T. A.; CAVALCANTE, L. F.; NUNES, J. C.; BEZERRA, F. T. C.; NUNES, J. A. S.; SILVA, A. R.; ORESCA, D.; CAVALCANTE, A. G. Effect of saline water, bovine biofertilizer and potassium on yellow passion fruit growth after planting and on soil salinity. African Journal of Agricultural Research, Lagos, v. 11, n. 32, p. 2994-3003, 2016. DOI: 10.5897/AJAR2016.11233 https://doi.org/10.5897/AJAR2016.11233

WAGNER JÚNIOR, A.; NEGREIROS, J. R. S.; ALEXANDRE, R. S.; PIMENTEL, L. D.; BRUCKNER, C. H. Efeito do pH da água de embebição e do trincamento das sementes de maracujazeiro amarelo na germinação e desenvolvimento inicial. Ciência e Agrotecnologia, Lavras, v. 31, n. 4, p. 1014-1019, 2007. Link:

http:// www.scielo.br/pdf/cagro/v31n4/11.pdf 